\title{
O możliwości komunikacji egzystencjalnej w filozofii Karla Jaspersa
}

About the Possibility of Existential Communication in the Philosophy of Karl Jaspers

We wstępie do polskiego wydania pism Karla Jaspersa jego ostatni uczeń, Hans Saner, kreśli skrótową ale bardzo interesującą charakterystykę swojego mistrza: „Filozof, który nieustannie pouczał, że «prawdą jest to, co nas wiąże» robił nie tylko wszystko, by nie związać z sobą nikogo - zdawał się niezdolny do komunikacji, jeśli uznać, że nie ogranicza się ona tylko do przekazu językowego" . Paradoks ten jeszcze silniej daje się dostrzec w korespondencji z Martinem Heideggerem, gdzie mimo deklarowanego pragnienia wytworzenia „więzi”, „wspólnoty myśli”, „filozoficznego królestwa ducha” Jaspers jawi się jako osoba bardzo silnie przywiązana do własnych poglądów, rzadko gotowa do ich rewizji, a w prywatnych relacjach niemal apodyktyczna². Podobne wnioski można by wysnuć po lekturze Autobiografii, gdzie we fragmentach poświęconych Rickertowi łatwo daje się odnaleźć również pozamerytoryczne źródła wzajemnej antypatii dwu myślicieli ${ }^{3}$. Rozdźwięk pomiędzy poczesnym miejscem, jakie w piśmiennictwie Jaspersa zajmowała problematyka komunikacji ${ }^{4}$, a samotnością i odosobnieniem, w które ów filozof niejednokrotnie pogrążał się na mocy własnej decyzji, z pewnością dałby się z bardzo ciekawym skutkiem zbadać biograficznie, być może owocne okazałyby się metody psychologii. Tego rodzaju historyczna analiza nie będzie jednak przedmiotem niniejszego artykułu. Zamie-

${ }^{1}$ H. Saner, Karl Jaspers. O rozległości rozumu i niezawodności działania, thum. D. Lachowska, w: K. Jaspers, Filozofia egzystencji, thum. D. Lachowska i A. Wołkowicz, Warszawa 1990, s. 5.

${ }^{2}$ Wniosek mój wypływa raczej z ducha tekstu niż z konkretnych, dających się jednoznacznie zinterpretować, fragmentów. Por. K. Jaspers, M. Heidegger, Korespondencja 1920-1963, tłum. C. Wodziński i M. Łukasiewicz, Torun 2000.

${ }^{3}$ K. Jaspers, Autobiografia, tłum. S. Turowicz, Toruń 1993, s. 35-39.

${ }^{4} \mathrm{Na}$ temat komunikacji pisał Jaspers przede wszystkim w 2. tomie Philosophie (1931), ale także w pracach pomniejszych. 
rzam bowiem podjąć problem komunikacji jedynie tak, jak występował on w filozoficznych pismach Jaspersa, a także korespondujące z komunikacją zagadnienie samotności.

Wydawać by się mogło, że najpierw jesteśmy samotni, a dopiero potem wchodzimy w więź z drugim człowiekiem. Filozof występuje jednak na przekór zdroworozsądkowemu doświadczeniu, punktem wyjścia czyniąc komunikację. Ciężko znaleźć w spuściźnie Jaspersa teksty, w których to samotność czyniłby głównym przedmiotem swego zainteresowania ${ }^{5}$. Jest ona zawsze „drugą stroną” komunikacji, innymi słowy - komunikacją (jeszcze) niezrealizowaną albo komunikacją zarzuconą. $Z$ tego powodu postaram się przede wszystkim zaprezentować filozoficzne znaczenie, jakiego pojęcie komunikacji nabrało w Jaspersowskiej odmianie filozofii egzystencji, a dopiero w drugiej kolejności, chcąc dochować wierności tematyce niniejszego tomu, pokażę, w jaki sposób samotność zawsze jest zagrożeniem, jak utrzymuje nas w napięciu i zmusza do ciagłego powtarzania woli nawiązania wspólnoty.

Ponieważ człowiek składa się z kilku wzajemnie przenikających się wymiarów, to istnieje wiele odmian komunikacji. Punktem wyjścia Jaspersowskiej antropologii jest Dasein $^{6}$. Jako empiryczne bycie tu oto (Dasein) dąży on tylko do zaspokojenia doraźnych potrzeb, wszelka komunikacja jest więc tylko wymiana informacji służących przetrwaniu. Zdaniem Jaspersa, jedynymi celami, które stawia przed sobą [człowiek jako] bycie tu oto (Dasein), są jego własne szczęście, przetrwanie, pomnażanie ${ }^{7}$. Pojawia się tutaj pierwotna forma łączności, wspólna człowiekowi i zwierzętom ${ }^{8}$. Przebiega ona dwuetapowo. Na zupełnie pierwotnym poziomie nie ma jeszcze samoświadomości, przez co potrzeby, sposoby ich re-

${ }^{5}$ W latach 1914-1915 Jaspers podejmował problem samotności jednostki w wykładzie na uniwersytecie w Heidelbergu. Analizy tegoż wykładu, dostępnego również w wersji drukowanej, podjęła się swego czasu C. Piecuch, a efekty jej pracy można odnaleźć w: C. Piecuch, Samotność jednostki (Z myśli Karla Jaspersa), „Annales Academiae Paedagogicae Cracoviensis”, Folia 30, Studia Philosophica II, 2005, s. 32-44.

${ }^{6}$ Termin ten nie doczekał się wśród tłumaczy Jaspersa jednolitej tradycji translatorskiej. Dość powiedzieć, że przekładano go między innymi jako 'istnienie', 'byt ziemski’ czy ‘byt empiryczny'. Mirosław Żelazny zaproponował przekładać Dasein jako b y ci e tu oto, co wydaje się o tyle słuszne, że wyrażenie to zawiera w sobie, po pierwsze, poznawalność (przez co rozumiem dostępność poznawczą w ramach jakiejś formy oglądu), po drugie zaś, temporalny charakter, to jest fakt, iż nigdy nie jestem jakimś Dasein w sposób stały, ale raczej z jednego Dasein, w zależności od sytuacji, przechodzę w inne. Obydwa te momenty charakteryzują Dasein, tak jak rozumiał ten termin Jaspers. Niezależnie od rozważań natury translatorskiej, pisząc Dasein, będę w niniejszym artykule miał na myśli siebie tu i teraz istniejącego, znajdującego się w określonej sytuacji historycznej, poznawalnego za pomocą metod biologicznych, psychologicznych oraz nauk społecznych. Por. M. Żelazny, Filozofia i psychologia egzystencjalna, Torun 2011.

${ }^{7}$ K. Jaspers, Rozum i egzystencja, tłum. C. Piecuch, w: tenże, Rozum i egzystencja. Nietzsche a chrześcijaństwo, Warszawa 1991, s. 83.

${ }^{8}$ Istnieją jednak spore różnice pomiędzy tym, jak rozumieją się zwierzęta, a zapośredniczonym rozumieniem, które jest udziałem ludzi. Por. tamże, s. 79. 
alizacji są wspólne wszystkim przedstawicielom danej grupy. Chcę tego, co wszyscy inni, gdyż nie dostrzegam jeszcze, że jestem inny niż wszyscy. Moja ontyczna odrębność nie jest jeszcze dla mnie dostępna, stąd nie zachodzi jeszcze komunikacja. Dopiero na kolejnym szczeblu uświadamiam sobie, że jestem nie tylko elementem świata, ale samoświadomym ja, które światu się przeciwstawia. Wówczas inni stają się dla mnie bezosobowymi, wymienialnymi i prawie niczym się od siebie nieróżniącymi istotami, które mogą mi w czymś pomóc albo które traktuję wręcz jak przedmioty - staram się ustawić w konfiguracji korzystnej z mojej partykularnej perspektywy'.

Powstała na tym gruncie quasi-wspólnota nigdy nie ma trwałego charakteru, lecz może istnieć tylko o tyle, o ile istnieją braki, których nie da się samodzielnie zapełnić. Wraz z ustaniem (zaspokojeniem albo samoistnym wygaśnięciem) potrzeby Dasein przestaje dopominać się o inne Dasein, przez co na nowo pogrąża się w samotności. Tego rodzaju relacje dalekie są od tego, co postulował Jaspers, przede wszystkim ze względu na zastępowalność jednostek biorących w nich udział. Poszczególne niedostatki, zwłaszcza te o charakterze witalnym, moga zostać zaspokojone przez dowolnego, byleby dysponującego odpowiednimi środkami, człowieka. Dla przykładu instytucja mamki dobitnie ukazuje, że dopóki chodzi tylko o organiczne potrzeby, dopóty nie ma większego znaczenia, kto pomaga je zaspokoić.

Ponieważ Dasein może być przedmiotem wiedzy, musi istnieć instancja dokonująca owego rozeznania. Gdy dokonuję obiektywnie ważnego poznania, a co może ważniejsze, gdy jego owoce komunikuję komuś innemu, czynię to zawsze z perspektywy świadomości w ogóle. Świadomość w ogóle (Bewusstsein überhaubt) to podmiot obiektywnie ważnej wiedzy, która z jednej strony jest nierelatywna względem podmiotu (tzn. to, czy pewne zdanie jest prawdą, nie zależy od tego, kto je wypowiedział), z drugiej jednak jakiś podmiot jest konieczny, aby ją wyrazić. Na gruncie filozofii egzystencji nie może być mowy o wiedzy, która nie jest w niczyim posiadaniu.

Nie jest konieczne osobiste zaangażowanie uczestniczących w takiej wymianie myśli jednostek, byłoby to wręcz niewskazane, czynnik ludzki należy eliminować i skupić się tylko na treści. Komunikacja taka zawsze zapośredniczona jest przez treści, które się wyraża, nie dochodzi do głosu wyjątkowość tego, który komunikuje. O ile w pierwszym przypadku mieliśmy do czynienia z tymczasową wspólnotą interesów, o tyle teraz pisze Jaspers o ponadczasowej, abstrakcyjnej, otwartej dla każdego, ale i nie faworyzującej nikogo, wspólnocie prawdy. Jest to jednak „tylko” prawda obiektywna, która nie może (i nawet nie rości sobie do tego prawa) wyzwolić z samotności egzystencjalnej. Nie oznacza to, że jest czymś zbędnym. Pisząc, „Racjonalność nie czyni mnie

\footnotetext{
${ }^{9}$ K. Jaspers, Philosophie, Berlin-Göttingen-Heidelberg 1948, s. 339-340.
} 
sobą samym, ale nie mogę stać się sobą nie będąc racjonalnym"10, Jaspers ukazuje wagę poznania naukowego. Uprawianie nauki jest jednym ze sposobów filozofowania, dopiero dotarłszy do jej granic, można dokonać skoku (Sprung) ku sferze egzystencjalnej. Dopiero, gdy wiem o sobie wszystko, co może mi powiedzieć biologia, chemia, fizyka, psychologia itp., uświadamiam sobie, że „Człowiek zasadniczo wykracza poza wszystko, co może o sobie wiedzieć"11, a zatem to, co da się bezpośrednio zakomunikować, nie wyczerpuje istoty człowieczeństwa.

Natomiast w sferze ducha porozumienie zachodzi za pośrednictwem wytworów. Przemawiają do nas teksty starożytnych poetów, potrafimy zrozumieć Michała Anioła, widzimy, w jaki sposób muzyka Wagnera mogła wpłynąć na tzw. ducha niemieckiego. To pokazuje, że mówiąc o komunikacji, mamy na myśli nie tylko bezpośrednią relację, w którą wchodzą podmioty w tym samym momencie dziejowym, ale rozważamy wszelkie formy ,przemawiania” jednej osoby do drugiej, na przykład poprzez dzieła sztuki czy przekazy historyczne.

Wszystko to jest tylko punktem wyjścia dla właściwej komunikacji. Jaspers podkreśla, że wszelkie wspólnoty, w rodzaju opisanych powyżej, istnieją tylko z e w z ględu na coś (kolejno: bezpośrednia korzyść, weryfikowalna prawda czy łącząca wielu ludzi idea, na przykład estetyczna), natomiast nie jest jeszcze istotne, „kto” je konstytuuje. Można tu przywołać iście dialogiczne stwierdzenie Jaspersa, że „być człowiekiem mogę tylko we wspólnocie z drugim”, choć sens tej wypowiedzi nie jest jeszcze w pełni wyraźny. Brak bezpośredniego oparcia na drugim uniemożliwiłby mi przetrwanie, niewiedza czyniłaby mnie bezradnym w świecie, natomiast wyobcowanie $\mathrm{z}$ uniwersum kultury pozbawiłoby mnie tożsamości. Samotność egzystencjalna, związana z egzystencjalnym „niebyciem-sobą”, jest czymś zupełnie innym. Mogę znakomicie odnajdywać się w świecie Dasein, odnosić sukcesy w dziedzinie obiektywnego poznania, aktywnie uczestniczyć w szeroko rozumianej kulturze, a zarazem nie wyklucza to głębokiej egzystencjalnej samotności.

Analiza komunikacji egzystencjalnej wymaga krótkiego wprowadzenia pojęcia egzystencja.

Egzystencja jest źródłem moich działań, jest czystą potencjalnością, stanowi o tym, kim mogę się stać (kim, w znaczeniu jakim byciem tu oto), czego moge dokonać, jak postąpię ${ }^{12}$. Mimo pewnych podobieństw nie można utożsamiać egzystencji z charakterem. Użycie tego terminu może mieć roboczy sens, ale utożsamienie tych pojęć byłoby błędem, jako że sam charakter bywa obiektem badania naukowego, między innymi psychologii, tymczasem egzystencja nigdy nie

\footnotetext{
${ }^{10}$ Tamże.

${ }^{11}$ K. Jaspers, Wprowadzenie do filozofii, thum. A. Wołkowicz, Wrocław 1998, s. 43.

${ }^{12}$ Por. M. Potępa, Antropologia filozoficzna Karla Jaspersa, w: Humanitas I. Z zagadnień filozofii i kultury wspótczesnej, Wrocław-Warszawa-Kraków-Gdańsk 1978, s. 207.
} 
staje się dostępna dla świadomości w ogóle. Charakter można, do pewnego stopnia, zobiektywizować, stąd już od starożytności pojawiają się próby typologii (np. sangwinik, choleryk, melancholik, flegmatyk), natomiast egzystencja zawsze jest jednostkowa i niepowtarzalna.

Nie można również egzystencji nazwać duszą. Przyczyna tkwi w tym, że dusza, w większości doktryn jest substancją samodzielną, która wiedzie swój żywot w zaświatach, gdy skończy się ziemska wędrówka człowieka ${ }^{13}$. Egzystencji nie można sobie wyobrażać jako bytującej p o z a byciem oto. Jako taka nigdy nie występuje ona samodzielnie w świecie, gdyż tutaj jestem zawsze tylko byciem tu oto, jednocześnie właśnie egzystencja jest źródłem tego, jakim byciem oto mogę się stać: „Egzystencja nie jest urzeczywistnionym byciem, lecz tym, co może być" 14 .

Dlatego egzystencja nie staje się nigdy obiektem poznania, tak jak rzeczy w świecie. W filozofowaniu nie chodzi o to, aby uzyskać na jej temat wiedzę. Zadaniem jest rozjaśnianie egzystencji, które można rozumieć dwojako. Po pierwsze - rozjaśnianie byłoby wydobywaniem z ciemności tego, kim jestem. Moja własna egzystencja jest dla mnie transcendentna w tym sensie, że nie jestem w stanie powiedzieć, jaki jestem naprawdę.

Drogami rozjaśniania egzystencji są: podejmowanie działań bezwarunkowych mających swe źródło w wolności, przeżywanie sytuacji granicznych oraz komunikacja. Skupię się tutaj tylko na tej ostatniej ${ }^{15}$. Samotność, którą uświadamiamy sobie w obliczu sytuacji granicznych (zwłaszcza cierpienia i śmierci), powoduje, że szukamy usensawniającej więzi z drugim, natomiast sytuacje graniczne walki i winy, jako że mają miejsce na skutek interakcji z drugim, same w sobie są już zalążkiem komunikacji.

Dzięki uczestnictwu w egzystencjalnej komunikacji z drugim człowiekiem mogę lepiej odkryć siebie i partnera. Możemy rozumieć się nawzajem, ale nie da się efektów tego rozumienia zakomunikować komuś innemu, gdyż wtedy doszłoby do nieuprawnionego uprzedmiotowienia egzystencji. Możliwe do pojęciowego wyrażenia jest tylko bycie tu oto. Mogę zestawić swoje i cudze Dasein, obserwować, czym się od siebie różnimy, werbalizować istniejące podobieństwa i różnice, ale jako egzystencje jesteśmy radykalnie różni, każdy jest wyjątkowy i przez to nie istnieje płaszczyzna pozwalająca dokonywać jakichkolwiek zesta-

${ }^{13} \mathrm{Z}$ tego powodu nieuprawnione wydają się próby zestawiania rozjaśniania egzystencji z obecnymi w teologii od czasów św. Augustyna próbami zrozumienia istoty duszy ludzkiej. Por. K. Michalski, Egzystencja ludzka jako właściwy , przedmiot” filozofii w myśleniu Karla Jaspersa, „,Ruch Filozoficzny", t. 55, nr 4, 1998, s. 605.

${ }^{14}$ Cyt. z Von der Wahrheit, za K. Michalski, Egzystencja ludzka jako właściwy „przedmiot” filozofii w myśleniu Karla Jaspersa, dz. cyt., s. 616.

${ }^{15} \mathrm{Na}$ temat działań bezwarunkowych por. D. Kolasa, Bezwarunkowy obowiqzek jako przejaw wolności w filozofii Karla Jaspersa, w: Karl Jaspers: Myślenie zaangażowane, red. C. Piecuch, Kraków 2011, s. 36-43. 
wień. Egzystencja jest więc tym, c o s i ę c z u j e, czego jest się pewnym, choć zarazem nigdy nie staje się tym, c o s i ę w i e. Mamy tu do czynienia z pewnością bez dowodu, z wiarą bez objawienia. Jestem pewien, że nie zawiodę, wierzę, że przyjaciel mnie nie zdradzi, bo nasze egzystencje są coraz bardziej rozjaśnione (w języku potocznym „znam siebie i znamy się nawzajem coraz lepiej”). Nie da się uzasadnić tej pewności, posługując się obiektywnym językiem świadomości w ogóle.

Drugim aspektem rozjaśniania egzystencji jest uczynienie siebie lepszym. Słowa „lepszy” nie należy rozumieć w sensie aksjologicznym, chyba że zgodzimy się na utożsamienie dobra $\mathrm{z}$ autentycznością. W tym sensie dobry to autentyczny, będący sobą, jedyny w swoim rodzaju ${ }^{16}$. Jest to ostatni etap drogi ku byciu sobą. Zaczyna się ona od bezrefleksyjnego współuczestnictwa w danej strukturze (np. społecznej), etapami pośrednimi są między innymi uprzedmiotawiające wykorzystywanie drugiego człowieka do realizacji swych potrzeb i abstrahująca od mojej osobistej konstrukcji wymiana informacji mających obiektywne znaczenie, a kresem może być głęboka więź z kimś, dzięki komu staję się sobą i kto dzięki mnie może stać się sobą.

Nie należy komunikacji egzystencjalnej rozumieć jako pewnej bezpośredniej interakcji, gdzie egzystencja przemawiałaby wprost do drugiej egzystencji. Medium komunikacji zawsze jest bycie tu oto ${ }^{17}$. Jakakolwiek strona ogarniającego, którym jestem, znajduje się na pierwszym planie - świadomość w ogóle czy duch, zawsze odbywa się to tylko w ramach pewnego dziejowego bycia tu oto. Wprawdzie świadomość w ogóle jest strukturą bezosobową, a duch ponadosobową ${ }^{18}$, a jednak żadne z nich nie mogłoby istnieć bez osób, przez które się wyrażają. Również egzystencja jest tym, co może realizować się tylko w byciu tu oto, nigdy nie może stać się czymś odosobnionym, jako takie dostępnym poznaniu.

Jaspers niejednokrotnie pisze o tym, że stać się autentycznie sobą możemy tylko dzięki drugiemu. Bycie z drugim wyprzedza bycie mną. Nie jest tak, że najpierw istnieję jako wyizolowana osoba, a później wchodzę w relację interpersonalną. To ów akt zbliżenia się do kogoś innego sprawia, że mogę w ogóle powiedzieć o sobie ,jestem" ${ }^{19}$. Dlatego pogrążanie się w samotności, unikanie autentycznej komunikacji z drugim, uniemożliwia mi zrealizowanie pełni swego człowieczeństwa.

Unikając otwarcia się na drugiego, ukrywam (przed nim i przed sobą samym) egzystencję, jednak trud zbliżenia mogę podjać w każdej chwili. Zdaniem Jasper-

${ }^{16}$ Por. K. Michalski, Egzystencja ludzka jako właściwy „przedmiot” filozofii w myśleniu Karla Jaspersa, dz. cyt., s. 609.

${ }^{17}$ Por. K. Jaspers, Wprowadzenie do filozofii, thum. A. Wołkowicz, Wrocław 1998, s. 17.

${ }^{18}$ Pisząc ,ponadosobowy”, mam na myśli to, że żadna odosobniona jednostka nie jest w stanie wytworzyć ducha.

${ }^{19}$ K. Jaspers, O mojej filozofii, tłum. D. Lachowska, w: tenże, Filozofia egzystencji, dz. cyt., s. $65-66$. 
sa, możliwość komunikacji nie ustaje nigdy, a to, czy zostanie ona zrealizowana, zależy tylko od nas, chociaż zdarzają się w historii momenty, gdy „brutalna samowola zamyka perspektywę porozumienia" ${ }^{20}$. Osamotniona jednostka nadal może podejmować próby filozofowania, zrozumienia siebie, jednak dopiero drugi nadaje tym próbom wartość i wypełnia je treścią ${ }^{21}$.

$\mathrm{Na}$ czym w praktyce polegać miałaby komunikacja zasługująca na miano egzystencjalnej, tego Jaspers nam nie mówi i powiedzieć nie może. Wynika to z faktu, że „nie da się podać jej modelu, nie da się jej skopiować; za każdym razem jest kategorycznie jedyna w swoim rodzaju"22. To jednak nie uniemożliwia podania pewnych ogólnych zasad, czegoś na kształt negatywnie sformułowanych warunków koniecznych. Ich spełnienie jeszcze niczego nie gwarantuje, ale gdy nie zostaną dopełnione, wtedy zachodząca relacja z pewnością nie będzie komunikacją egzystencjalną.

Jaspers pisze w sposób następujący:

Z komunikacji wypływają najjaśniejsze momenty, ich bogactwo składa się na wagę życia. [...] Człowiek nie może wynosić się nad drugiego człowieka, bo do drugiego zbliżyć się może tylko ten, kto się z nim spotyka na równym poziomie. Drugiego człowieka nie można pouczać o jego powinnościach, ale można wraz z nim poszukiwać tego, czego się chce i czym się jest ${ }^{23}$,

a w innym miejscu „Nietzsche widzi następnie istotną przyczynę tej samotności w tym, że prawdziwa komunikacja jest możliwa tylko na równym poziomie. Nie może się ona udać ze stojącymi wyżej lub niżej”24.

Nie można wobec tego traktować partnera jedynie jako środka do osiagnięcia celu. Dopóki oczekuję od innego człowieka wsparcia w jakiejś sprawie, pragnę, by pomógł mi rozwiązać problem, nie ukazuje się jego egzystencja. Dzieje się tak dopiero wtedy, gdy moim celem stanie się otwarcie się przed nim i $\mathrm{na}$ jego egzystencję. Widać tu echa myśli Kanta, który w drugiej formule imperatywu nakazywał w człowieczeństwie dostrzegać zawsze również cel sam w sobie, a nie tylko środek do realizacji zewnętrznych zamierzeń2 ${ }^{25}$. Konieczna jest autoteliczność komunikacji - aby odsłonić przed drugim swą egzystencję, nie mogę pragnąć niczego więcej, jak tylko bycia z nim. Jeśli korzystam z drugiego

${ }^{20}$ Tamże. Takim okresem miał być na przykład narodowy socjalizm w Niemczech i będąca jego efektem zbrodnia Holokaustu.

${ }^{21}$ C. Piecuch., Samotność jednostki (Z myśli Karla Jaspersa), dz. cyt., s. 36.

${ }^{22}$ K. Jaspers, Philosophie, dz. cyt., s. 345.

${ }^{23}$ Tenże, Filozofia. Wprowadzenie do filozofii, thum. D. Kolasa i M. Żelazny, „Filo-Sofija”, 1(9), 2009, s. 221.

${ }^{24}$ Tenże, Nietzsche, tłum. D. Stroińska, Warszawa 1997, s. 73. Choć w cytowanym fragmencie Jaspers pisze, jakby rekonstruował tylko stanowisko Nietzschego, z kontekstu wypowiedzi możemy wnioskować, że jest to również jego własne stanowisko.

${ }^{25}$ I. Kant, Ugruntowanie metafizyki moralności, tłum. P. Zarychta, Kraków 2005, s. 55 i nn. 
dla zaspokojenia pewnej potrzeby (niekoniecznie nadając słowu „korzystać” pejoratywne znaczenie, kojarzące się z wykorzystaniem, wyzyskiem) lub komunikuję mu treści, w odniesieniu do których nie ma znaczenia, kto jest ich wyrazicielem, to komunikacja nie zasługuje jeszcze na miano egzystencjalnej. Stanie się tak dopiero wtedy, gdy drugi będzie dla mnie celem w całej rozciąłości, gdy moje wyjście ku niemu będzie wszystkim, czego pragnę.

Warto wobec tego zauważyć, że niektóre sytuacje, które intuicyjnie uznalibyśmy za rozjaśniające egzystencję, jak na przykład sakrament pokuty, w rzeczywistości nie spełniają tej funkcji, ponieważ z góry zakładają niesymetryczność poziomów, na których znajdują się duchowny i penitent ${ }^{26}$. Również wszelkie formy terapii nastawione na dokonanie zmiany w drugim człowieku w myśl założonego uprzednio celu traktują go jako podatny na kształtowanie przedmiot, a nie jako jedyną w swoim rodzaju egzystencję. Psychoterapia uprawiana w duchu egzystencjalnym miałaby więc na celu nie tyle dopasowanie pacjenta do założonego z góry wzorca, ile raczej poszukiwanie takiego sposobu życia (takiego „,bycia tu oto"), który byłby jak najbardziej zgodny z duchową konstytucją (egzystencją) konkretnego podopiecznego.

Relację między odsłaniającymi się sobie nawzajem egzystencjami utożsamia Jaspers z miłością, pisze o miłosnej walce. Walka jest jedną z sytuacji granicznych. Jednakże to nie prowadzona przemocą walka o przetrwanie, oparta na rywalizacji i wykluczeniu tych, którzy dali się pokonać, nadaje sens naszemu bytowaniu, ale komunikacja nastawiona na wspólną walkę o egzystencję. Autentyczna miłosna walka zawiera w sobie moment otwarcia się na siebie obydwu stron. Brak wzajemności jest zasadniczym ograniczeniem komunikacji. „Z kimś, kto rzeczywiście chce prawdy, a więc i komunikacji, można po prostu mówić otwarcie o wszystkim; może to czynić i druga strona, tak jednak, aby ani nie urazić, ani nie oszczędzać zbytnio tego, kto istotnie chce posłyszeć prawdę"27. Miłosna walka w wielu aspektach różni się od rywalizacji, między innymi nigdy nie zakłada uzyskania [nad drugim - D.K] przewagi czy przezwyciężenia go; nie ma miejsca na kalkulacje i wyrachowanie, konieczna jest wzajemna przejrzystość. $\mathrm{O}$ zwycięstwie można mówić tylko wtedy, gdy stanie się ono udziałem obydwu uczestników - gdy razem przezwyciężą zewnętrzne i wewnętrzne ograniczenia ${ }^{28}$ i odnajdą swą wspólną prawdę. Prawdą zaś jest taki sposób bycia razem, dzięki któremu ,pokonując samych siebie zarazem stają się w pełni sobą" ${ }^{29}$.

Zadanie, które stawia przed nami Jaspers, wygląda więc następująco - drugi człowiek ma być dla nas ważny w całej swej historii, należy zaakceptować jego

${ }^{26}$ C. Piecuch, Samotność jednostki, dz. cyt., s. 40.

${ }^{27}$ K. Jaspers, O źródle i celu historii, tłum. J. Marzęcki, Kęty 2006, s. 155.

${ }^{28}$ Pisząc o ,wewnętrznych ograniczeniach”, mam tu na myśli przede wszystkim egoizm, który jest cechą nieodłączną człowieka jako Dasein.

${ }^{29}$ Por. K. Jaspers, Philosophie, dz. cyt., s. 351. 
egzystencję ${ }^{30}$. Gotowość do zakwestionowania i niejako wzięcia w nawias własnych przekonań jest niezbędna dla otwarcia się na drugiego człowieka. Teraz bowiem treści stają się drugoplanowe, a chcę dostrzec ukrywającą się pod nimi egzystencję. Zabsolutyzowanie i uznanie własnego światopoglądu za jedyny prawdziwy jest końcem wszelkiej komunikacji, uniemożliwia ujawnienie egzystencji, gdyż dopóki trwam w świecie własnych przekonań, dopóty nie jestem gotów zrozumieć egzystencji, a za zupełne uważam to bycie tu oto, w którym aktualnie się realizuję ${ }^{31}$, czyli - mówiąc innymi słowy - zamykam się w sobie, uznając się za w pełni ukształtowanego, wykończonego, najlepszego z możliwych.

Większość ograniczeń komunikacji nie należy do istoty samego procesu, ale wynika z dających się zaobserwować cech przejawianych przez uczestniczących w niej ludzi. Jaspers wymienia między innymi: brak zrozumienia; uległość wynikająca z chęci zaprzestania konfrontacji, a nie z autentycznej zgody na optykę drugiego; defensywne podejście do dialogu uniemożliwiające przebicie się przez pancerz własnego punktu widzenia. Warto również zauważyć, że to nie swoboda i łatwość wymiany myśli świadczy o wartości komunikacji, ale rzeczywiście przejawiające się przez nią odsłonięcie własnej egzystencji: „To nie nawiązywanie kontaktu i wymiana myśli, nie przyjacielskość i towarzyskość są drogą komunikacji, ale dopiero bezustanne podążanie ku całościowemu objawianiu siebie"32. Nie zawsze musimy być zadowoleni z owoców autentycznie egzystencjalnej komunikacji. Nierzadko to, kim naprawdę jestem, nie jest w pełni kompatybilne ani z tym, kim chciałbym się stać, ani nawet $\mathrm{z}$ moim aktualnym postrzeganiem siebie samego. Rozjaśnienie egzystencji może wywołać psychologicznie przykre konsekwencje w byciu tu oto (Dasein) ${ }^{33}$.

Samotność jest drugim biegunem, nieodłącznym od komunikacji.

Komunikacja zawsze ma miejsce pomiędzy dwojgiem ludzi, którzy łączą się, zarazem pozostając dwojgiem [nie pojawia się figura „osoby zbiorowej” ani żaden tego rodzaju konstrukt, czyniący z dwojga niezależnych istot jedną, w której „roztapiała-

\footnotetext{
${ }^{30}$ K. Jaspers, Wiara filozoficzna, tłum. J. Garewicz, D. Lachowska, M. Łukaszewicz i A. Buchner, Toruń 1995, s. 121.

${ }^{31}$ Por. tamże.

${ }^{32}$ K. Jaspers, O mojej filozofii, dz. cyt., s. 64.

${ }^{33}$ Dysonans pomiędzy projektowanym ,,ja”, a tym, kim jestem rzeczywiście, najwyraźniej daje o sobie znać w obliczu sytuacji granicznych. Ponieważ są one za każdym razem niepowtarzalne i jedyne w swoim rodzaju, przeto nigdy nie mogę w pełni przewidzieć, jak zachowałbym się na przykład w obliczu śmierci kogoś bliskiego czy w momencie, gdy przyjdzie mi skonfrontować swe Dasein z niesprzyjającymi okolicznościami świata zewnętrznego. Sytuacja graniczna winy (wina egzystencjalna) polega właśnie na tym, że mój konkretny czyn jawi mi się jako niezgodny z moją egzystencją. Dopiero post factum wiem, co pow in i en e m był uczynić, ale wówczas jest już za późno. Bezwarunkowy obowiązek mogę podjąć tylko tu i tera z.
} 
by" się tożsamość każdego z uczestników komunikacji - D. K.]. Wychodzą one ku sobie z samotności, a o samotności wiedzą dopiero dzięki temu, że się komunikują ${ }^{34}$.

Samotność nie może więc na gruncie filozofii Jaspersa istnieć jako nieuświadomiona. Jest ona czymś innym niż społeczne odosobnienie, gdyż to ostatnie może stać się udziałem również dzikusa, który wskutek złamania pierwotnego tabu został wydalony poza obręb wspólnoty. Poczucie samotności wymaga pewnego stopnia samoświadomości. Jaspers trafnie ukazuje podstawową sytuację człowieka, który potrzebuje drugiego nie tylko po to, by się narodzić i przetrwać w pełnym niebezpieczeństw świecie; nie tylko po to, by umieć ten świat interpretować, ani nawet nie po to, by nie pozostać w tymże świecie istotą na podobieństwo zwierząt. Ludzka potrzeba więzi dotyka najbardziej osobistych i niemożliwych do zakomunikowania obszarów ,ja”. To dzięki drugiemu człowiekowi wiem, że jestem, i upewniam się, kim jestem. Owo communio ergo sum jest filozoficznym credo Jaspersa.

\section{BIBLIOGRAFIA}

Jaspers K., Autobiografia, tłum. S. Tyrowicz, Toruń 1993.

Filozofia. Wprowadzenie do filozofii, tłum. D. Kolasa i M. Żelazny, „Filo-Sofija”, 1(9), Bydgoszcz 2009.

Jaspers K., Filozofia egzystencji, tłum. D. Lachowska i A. Wołkowicz, Warszawa 1990. Jaspers K., Nietzsche, tłum. D. Stroińska, Warszawa 1997.

Jaspers K., O źródle i celu historii, tłum. J. Marzęcki, Kęty 2006.

Jaspers K., Philosophie, Berlin-Göttingen-Heidelberg 1948.

Jaspers K., Rozum i egzystencja. Nietzsche a chrześcijaństwo, Warszawa 1991.

Jaspers K., Wiara filozoficzna, thum. J. Garewicz, D. Lachowska, M. Łukaszewicz i A. Buchner, Toruń 1995.

Jaspers K., Wprowadzenie do filozofii, tłum. A. Wołkowicz, Wrocław 1998.

Jaspers K., Heidegger M., Korespondencja 1920-1963, tłum. C. Wodziński i M. Łukasiewicz, Toruń 2000.

Kant I., Ugruntowanie metafizyki moralności, tłum. P. Zarychta, Kraków 2005.

Karl Jaspers: Myślenie zaangażowane, red. C. Piecuch, Kraków 2011.

Michalski K., Egzystencja ludzka jako właściwy „przedmiot” filozofii w myśleniu Karla Jaspersa, „Ruch Filozoficzny”, t. 55, nr 4, 1998.

Piecuch C., Samotność jednostki (Z myśli Karla Jaspersa), „Annales Academiae Paedagogicae Cracoviensis", Folia 30, Studia Philosophica II, 2005.

\footnotetext{
${ }^{34}$ K. Jaspers, Philosophie, dz. cyt., s. 347.
} 
Potępa M., Antropologia filozoficzna Karla Jaspersa, Humanitas I. Z zagadnień filozofii i kultury wspótczesnej, Wrocław-Warszawa-Kraków-Gdańsk 1978.

Żelazny M., Filozofia i psychologia egzystencjalna, Toruń 2011.

\begin{abstract}
The author tries to present different aspects of communication, which can be found in the philosophical work of Karl Jaspers. The beginning point is an immediate communication taking place in existence, and the goal is an existential communication, which enables existential elucidation. Jaspers believes that only in contact with other people one can be himself. Solitude is never a good answer to our problems.
\end{abstract}

\title{
Keywords
}

Karl Jaspers, Philosophy of Existence, Existence, communication, solitude, loving-struggle

\section{Słowa kluczowe}

Karl Jaspers, filozofia egzystencji, egzystencja, komunikacja, samotność, miłosna walka 